Systemy Logistyczne Wojsk

Zeszyt 55 (2021)

ISSN 1508-5430, s. 137-158

DOI:

Military Logistics Systems

Volume 55 (2021)

ISSN 1508-5430, pp. 137-158

DOI:
Instytut Logistyki

Wydział Bezpieczeństwa, Logistyki i Zarządzania

Wojskowa Akademia Techniczna

w Warszawie

Institute of Logistics

Faculty of Security, Logistics and Management Military University of Technology

in Warsaw

\title{
Hazard and risk analysis in the logistics safety system based on international quality requirements
}

\author{
Analiza zagrożeń i ryzyka \\ w systemie bezpieczeństwa logistycznego w oparciu \\ o międzynarodowe wymagania jakościowe
}

\author{
Agnieszka Anna Klasa \\ klasa.agnieszka@gmail.com; ORCID: 0000-0003-4777-2641 \\ Wojskowa Akademia Techniczna, Wydział Bezpieczeństwa, Logistyki i Zarządzania
}

\begin{abstract}
The publication presents an analysis of hazards and risk in the logistics safety system conducted on the basis of international quality requirements. The definitions of the hazard and risk, as well as the methodology of analysis and the process of managing them in the company were presented. The next part of the article author presents the place of hazards and risk analysis in international quality standards. The mechanism of risk analysis as a quality assurance system in British, American and Polish defense has been approximated. Finally, an example of implementing the requirements of the quality management system for the aviation, space and defense in a Polish company was presented. The analysis of hazards and risk associated with them on the basis of an example and based on international standards is aimed at justifying the hypotheses regarding the impact of risk analysis on decision-making processes in the company. The research methods used are the cause and effect analysis, the synthesis of information with the use of numerical and logical association in order to collect structured objective evidence. The result of the research is the confirmation of the hypotheses for the risk management process. The risk management process is a continuous process and affects the achievement of the company's strategic targets. The key factor for the actual implementation of hazards and risk analysis in the company is personnel trained in accordance with the positions held. An additional factor is how to understanding and implementing the company risk management process
\end{abstract}

Keywords: risk analysis, international quality standards, industry 4.0, human recources, AS 9100 ver D

Abstrakt. Publikacja prezentuje analizę zagrożeń i ryzyka w systemie bezpieczeństwa logistycznego prowadzonego na podstawie międzynarodowych wymagań jakościowych. Przedstawione zostały definicje zagrożenia i ryzyka oraz metodyka analizy i procesu zarządzania nimi w przedsiębiorstwie. W dalszej części 
artykułu zaprezentowano miejsce analizy zagrożeń i ryzyka w międzynarodowych standardach jakościowych. Przybliżono mechanizm analizy ryzyka jako narzędzia zapewnienia jakości w brytyjskich, amerykańskich i polskich procedurach obronnych. Na koniec przedstawiono przykład wdrażania wymagań systemu zarządzania jakością dla przemysłu lotniczego, kosmicznego i obronnego w polskim przedsiębiorstwie. Analiza zagrożeń i ryzyka z nimi związanego na przykładzie i w oparciu o standardy międzynarodowe ma na celu uzasadnienie postawionych hipotez dotyczących wpływu analizy ryzyka na procesy decyzyjne w przedsiębiorstwie. Metody badawcze zastosowane to analiza przyczynowo - skutkowa, synteza informacji z zastosowaniem kojarzenia numerycznego i logicznego celem zebrania uporządkowanego materiału dowodowego. Rezultatem badań jest potwierdzenie postawionych hipotez dla procesu zarządzania ryzykiem. Proces zarządzania ryzykiem jest procesem ciągłym i wpływa na osiąganie celów strategicznych przedsiębiorstwa. Kluczowym czynnikiem dla faktycznego wdrożenia analizy zagrożeń i ryzyka w przedsiębiorstwie jest przeszkolony personel stosownie do zajmowanych stanowisk. Dodatkowym czynnikiem jest sposób zrozumienie i wdrożenie procesu zarządzania ryzykiem w przedsiębiorstwie.

Słowa kluczowe: zarządzanie ryzykiem, międzynarodowe standardy jakości, Przemył 4.0, zasoby ludzkie, AS 9100 ver D

\section{Introduction}

Despite the risks arising from the economic situation, which is a result of the annual global instability triggered by the COVID-19 pandemic, the Polish industry and services thrive on science, innovations and international cooperation in the field of experience, research and development. A significant issue is the supply and service chain management from beginning to end both in terms of transport and design. A supply chain based on the international standards gives an organization the opportunity to build a mutually beneficial supplier-customer relationship. By working together, time and costs of supply can be reduced. Ultimately, it will translate in the improved customer satisfaction and convince the customers to to take advantage of the offers again, including the offers from the Polish companies. A key phenomenon is the involvement of employees and decision-making based on hazard and risk analysis that pursues company's strategic objectives. All these factors can be developed on the basis of international quality standards.

By implementing the international quality standards, work efficiency is increased thanks to the clarity on responsibilities and competencies and by enhancing the trust of our suppliers and customers. We rationalise costs and reduce adaptation time for new employees and suppliers. In addition, by meeting the quality and safety requirements of future international customers, we minimize the risk of providing supply or service that does not meet customer requirements. Thus, we enhance the life cycle of a product or service. Most importantly, we ensure a certain quality of delivery and service.

\section{Research methodology}

A problem related to the implementation of mechanisms for the risk analysis at all levels of management in the Polish enterprises was observed while carrying 
out the tasks and analysing the situation on the Polish market. This phenomenon, namely the impact of risk analysis on the decision-making processes within the company, was definied as the research problem. The following research questions have been identified to visualize the research problem:

1. How is risk analysis carried out in the organization?

2. How is risk managed at different levels of management?

3. What impact do the monitoring and controlling activities related to risk have on risk levels?

4. What is the attitude of the personnel to the risk management process in the organization?

The following research hypotheses were identified as part of the analysis of the reseach problem:

Hypothesis 1: Hazard and risk analysis in an organization is carried out on an ad hoc basis.

Hypothesis 2: The risk management process is not documented at different management levels and is performed for evidence purposes for internal and external audits.

Hypothesis 3: There is an added value for the organization in the continuous monitoring of risk mitigation actions.

Hypothesis 4: The personnel, convinced of the validity and purpose of risk analysis and management, carries out this process continuously and with tangible results for the company.

The research subject is an organization, a company operating in the international civil market, which has decided to try to integrate its services and supplies into the national and international supply chain for the aviation and military industry.

The research sample is a production area, which is to be adapted to international requirements for the aviation and defense industry for a particular product. The market investigation in the field of development and acquisition of new contracts forced the company to take action to implement a quality management system for the defense and aviation industry in order to expand its services to new contracts.

The aim of the research is to demonstrate the importance of hazard and risk analysis in the decision-making and operational process in a company wishing to enter the defense and aviation services market based on the requirements of quality standards.

The research methods used in the study include a cause and effect analysis of the documents which set out the requirements in the area of risk analysis and in the documented risk analysis process in the organization and in the quality standards. In the next stage, a synthesis of information was applied with the use of numerical and logical association in order to put the collected evidence in a logical order. The theory of the research problem was finally defined through the analysis and observations of the factual situation in the company and the experience in this area of research. 
The research techniques used in the research methods include: observation, analysis and examination of the source documents and facts on the production line through sampling along with analysis of the synthesis results.

The research tool used as part of the research techniques is a document analysis sheet. Interviews and participatory observation were used to analyze the documented process and monitor risk. The cause and effect association was determined through the use of synthesis results sheets.

The sources of information used for this study in the above-mentioned area and tasks are obtained from the risk analysis guidelines for organisations operating under international quality requirements. These are important aspects for companies aspiring to provide defense services and supplies: internal procedures and process maps, national guidelines within current legislation and experienced employees who have the right contacts, qualifications and certifications.

The research hypotheses will be verified based on the analysis of documents, relations and responsibilities between employees, and conclusions from the facts.

The structure of this article first presents the concepts of hazards and risks and follows with hazard and risk analysis, phases and management. In the following part, an analysis of national and international formal and legal regulations for meeting the requirements of the quality management system will be presented. The research problem will be explained by using an example and the hypotheses will be verified by demonstrating the importance of risk analysis in the selected area of activity.

\section{Concepts of hazard, risk and their analysis and management}

There is a great number of definitions of risk in the source literature. Having analyzed them, it can be stated that the clearest definition is the one which specifies hazard as an event that can occur and will have a negative impact on the achievement of the adopted objectives. Risk is measured by the severity of the impact and the likelihood of its occurrence (ISO 31000:2009, 2009). Risk is the result of the analysis of a situation or condition, i.e. a threat triggered by external factors or a person, that causes a sense of security to diminish or entirely disappear. Risk occurrence probability is a numerical designation of risk in the reality (Czerwiński, Grocholski, 2003).

The purpose of risk management is to increase the likelihood of fulfilling the outcomes and tasks by reducing the likelihood of risk and providing protection against its potential consequences (Ficoń, 2021). This shall be done through a rational hazard assessment and the resulting risk identification. The following section will focus on determining the significance and possibility of risk occurance related to the activities of the company, and the risk measurement. Risk and its relevance for the organization are evaluated in order to identify the impact of risk on the decisions and realization of tasks. This activity enables the risk monitoring and control at a later stage. 
The risk management process is implemented by company's employees and occurs in all areas of company's activity. The risk management process is a continuous process and is not limited to being carried out on individual work positions or ad hoc. Depending on the levels of risk management, the responsibilities and authority should be defined at the different levels of management of the company.

Hazards and risks are analyzed, identified, determined, monitored and controlled in accordance with the hierarchy of business objectives in the enterprise, which are defined by plans and strategic documents at each level. At the operational and project level, risk management focuses on the core processes of delivering a product to a customer and providing a service.

Defining clear, consistent goals and tasks, which are compliant with the mission of the company and are set at each management level, is an essential prerequiste for risk management in the enterprise. Another key elements are the establishment of measurable indicators of achievement of the adopted goals and tasks, determination of the risk level acceptable for the adopted goals and tasks, and ongoing monitoring of their implementation. In the monitoring process, it is important to conduct an analysis of the correctness and application of control mechanisms to ensure the correctness of the risk analysis and its verification (Makowski, 2020).

At the management level, risk is monitored with respect to its impact on business objectives. A system assessment and suggested corrective and preventive actions should be submitted to decision makers. Managers of enterprises should continuously carry out the risk analysis in terms of hazards to the achievement of business objectives, including hazards at the level of financial risk, e.g. changes in the material and financial plan, exchange rates and interest rate changes, liquidity risk and working capital management.

At the operational and project level, risk that is identified within the assigned areas of activity must be subject to an assessment process in order to apply adequate corrective mechanisms or mitigating actions. The next stage of risk management is the implementation of risk management recommendations.

The level of risk and related hazards is verified by means of risk monitoring and control. Depending on the management level, the scope of authority may vary. At the management level, the risk management process may include the approval of the documents and/or their adoption for use within the enterprise. These documents contain overall tasks and guidelines covering the area of risk management, including in particular strategic plans, material and financial plans, business plans and programmes for undertakings. It is recommended to perform cyclical and ad hoc analytical work, plan the risk management process, and accept or reject the results of analytical work.

At the operational level, risk owners analyze hazards and identify, monitor and evaluate risk in accordance with the adopted principles and standards in the enterprise. They implement recommendations concerning the management of different 
risks within the framework of the adopted principles. As regards the defined risks, they focus on monitoring and implementing mitigating actions.

The activities of the risk management cycle cover all levels of management and are implemented through hazard and risk analysis to reduce uncertainty in the achievement of the objectives of the company. Decisions on how to deal with risk are made after analysing the relevance of the risk to the enterprise, i.e. determining whether the level of risk is acceptable and whether the risk is relevant to the decision-making process. For the purpose of achieving the expected response to the risk, it is essential to determine what measures are necessary to effectively mitigate the risk and whether these measures are available, and establish mitigating actions (Bogdanienko, 2020).

In order to measure risk and the likelihood of risk occurrence, a risk matrix is used. It depicts the severity of the identified risk and its likelihood of occurrence (Ficoń, 2021).

Risk reaction or risk response involves determining a company's strategy to deal with risk at a given level. A company can tolerate a given level of risk, which means that the costs of effectively addressing risk may exceed its potential benefits, and the ability to effectively address risk is limited or beyond external decisions and actions. For the sake of a significant reduction of risk or its elimination, the organization can also apply mitigating actions. The response to the risk may cause the risk to be postponed or temporarily stopped. Another possible strategy is risk transfer, where risk is shifted to another entity. Common examples are insurance or outsourcing (Ficoń, 2021).

The key part of the overall risk management process is risk monitoring and control, which should be carried out by risk owners at each management level. This approach allows for an adequate risk response by providing possibilities to reduce risk through mitigating actions or enables to apply a different strategy depending on the changing conditions and hazards shaping the risk.

Considering the standard scheme of enterprise risk management presented in the source literature, it is important to ensure the proper implementation of mechanisms that work in the same way for national and foreign requirements in the civil and military markets. The risk management process is used and required in international standards and the process itself has been described and modified over many years.

\section{Hazard and risk analysis in the international quality standards}

While setting business objectives, enterprises are threatened by many errors during decision-making in the process of management and constant need to adapt to a changing marketplace. Due to the constant lack of complete and reliable 
information from the environment surrounding the enterprise, every decision made by the enterprise is fraught with risk, and each manager takes actions related to risk identification, measurement and mitigating actions. Decison-making is supported by risk analysis. The major experience of institutions involved in the research actvities concerning risk management process and collecting research data has consequently defined risk trends and standards in various areas and disciplines (Kulinskaya, 2019). Thanks to this approach, a risk management model has been developed and it has been evaluated over the years.

One of the risk management methods in enterprises is the COSO II method. The name derives from the abbreviated title of a publication issued by the American private sector organization COSO (The Committee of Sponsoring Organisations of the Treadway Commission) which was implemented on the Polish marked in 2004. COSO describes the principles and concepts that provide guidance for assessing and improving the effectiveness of risk management at all levels of an organization. Risk management method compliant with COSO is intended for enterprises of all sizes and types. This system is universal and can be adapted to any company strategy and its specific operations. The COSO model includes activities such as process monitoring, obtaining information, horizontal and vertical communication, control activities, hazard identification, risk evaluation and defining the company's internal control environment. The basic steps in the COSO method are presented in the figure below (Czerwiński, Grocholski, 2003):

\section{Establishing}

objectives
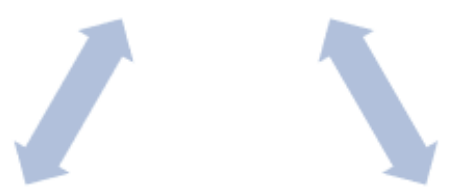

Defining scope of internal control

Evaluating hazards and associated risk

Fig. 1. Basic steps in the COSO model Source: Author's own elaboration 
Over time and with increasing experience in hazard and risk analysis, the Australian Standard AS/NZS 4360:2004 was developed. It provides a generic framework for risk management and control and is the most widely used standard applied to various risk management processes. The risk management concept used in this standard covers guidance for establishing an appropriate infrastructure and culture. It is suggested to use a logical and systematic method for establishing the context, risk identification, analysis and evaluation, implementation of mitigating actions, and monitoring and communicating the risks associated with any activity or process in a manner that allows enterprises to minimize losses and maximize profits. The described process applies to the management of both potential gains and potential losses. This standard provides a general guide for risk management and can be applied to a very wide range of activities, decisions or operations of any public, private or community enterprises, groups and individuals. This standard is generic and is not desginated for any particular industry or business sector. The design and implementation of a risk management system are influenced by the needs of the enterprise, its operational and strategic objectives, its products and services, and the adopted processes and practices.

Based on the COSO standards and the developed trend, the international standard ISO 3100:2009 was developed in 2009. It introduced risk management principles based on FERMA, COSO II and AS/NZS 4360:2004 standards (Ficoń, 2021). The standard itself is an expanded and developed version of AS/NZS 4360:2004, which became subject to public consultation in Australia and New Zealand. Although the standard provided generic guidance, it was not intended to promote uniformity in risk management across organisations. The creation and implementation of risk management plans and frameworks cover the different needs of a specific company, its tasks, the specifics of operations, structure, processes, products and services, and the specific practices used for a given industry. In 2018, a revision of ISO 31000 standard was published to provide advanced principles and generic guidelines for the risk management process. Input data is subject to verification and consultation to establish the context for the risk assessment within the scope of the risk identification, analysis and evaluation. The resulting assessment is continuously monitored and reviewed to verify it against the changing facts in the enterprise.

Based on these international standards and procedures, risk management has become a structured process that should be an integral part of enterprise management. It should be well-communicated, put in practice and aligned with strategic objectives of the enterprise.

It is important to point out that the analysis of hazards and associated risk is essential to manage a company's objectives, regardless of the industry or area of activity. Every enterprise operating on the market is exposed to the impact of environmental factors, political, cultural, social, legal and financial changes, random events, and force majeure (Moraczewska, 2021). 
In an enterprise focused on development and continuous improvement, the team enhancing their own and the enterprise's competencies has a common vision and approaches solutions in a systematic way. Standardized and continuous risk analysis in all areas of development effectively minimizes additional financial, material and personnel expenses in the organization (Bogdanienko, 2020).

\section{Risk analysis as a quality assurance tool in defense procedures}

The instructions used to ensure the supply of equipment and services in the defense sector repeatedly inlude conducting a risk analysis as a requirement for each concluded contract, which provides for the application of the customer's quality requirements and specified standards (Braman, 2018).

Based on the Polish guidelines, established among other by decisions or internal procedures, the audits and analyses of facts seek to identify an uncertain event or condition, which is likely to occur and at the same time may have a negative impact on the fulfilment of quality requirements specified in the contract (Ministry of National Defense, 2019).

Tools that are used include risk identification, assessment and communication forms attached to the procedure for the purpose of using them in the activities performed. Within the defense procedures, risk analysis is a key element used to monitor and control the implementation of quality clauses at the stage of contract preparation and execution. These activities cover issues related to risk management in the supply chain and military services where external entities participate in the quality assurance procedure. The external entity for the Polish contracts is for example the regional military representative, whereas for subcontractors or foreign contractors - the government quality assurance representative (Ministry of National Defense, 2019). The risk analysis procedure begins with reviewing the contract, regardless of who executes the contract.

The designated representative of the ordering party conducts a review of the contract in terms of compliance with the documentation, thus initiating the process of agreeing on the principles of future cooperation as part of the contract, combined with hazard and risk analysis. A stage of preparation of the parties for the subsequent handover of the product for use includes the designation of an appropriate person to supervise quality and the indication of the quality assurance procedure in the contract or in the annexes.

Following examples are the basis for the non-compliance with the formal requirements for the customer: omitting the moment of approval of the product by the relevant institutions, lack of appropriate examinations and tests, not issuing appropriate certificates to the requirements for releasing the product from the contractor's or subcontractor's workshop with the required documents confirming 
the compliance of the products with the customer's and quality requirements (Staniewska, 2021). The person responsible for reviewing the documentation with the contract presents the findings of the review including identification of risk areas, and prepares conclusions for implementation along with with the approach to the identified risk. The overall risk analysis process is subject to a continuous improvement process, which is monitored and controlled until the contract is executed.

The aim of the activities related to the risk analysis process is to minimize the deviations from customer requirements contained in the contract and other quality requirements. In practice, the mechanisms introduced by national regulations are based on the international defense quality standards and other military standards (Rogowski, Woźniak, 2018). One such example is Decision Nr 427/MON of the National Defense Minister from 29 October, 2014 concerning specification of functioning rules for the quality assurance system, customer's obligations, regional military representation (RMR), owner of the military equipment and the central logistic agency, and the Military Centre for Standardization, Quality and Codification (MCSQC) for assuring the quality of defense products. Both risk analysis and product quality system management issues are implemented on the basis of this regulation and international standards. Supply and service processes in the defense area are covered by NATO requirements and internal regulations concerning the industrial security and protection of classified information. In terms of classified information, issues related to the requirements for industrial security degrees should be taken into account. These degrees are issued by the Military Counterintelligence Service for the military and by the Internal Security Agency for the civil sector.

Polish defense regulations are based on a standardization agreement which defines process, procedures, terms and conditions for common military or technical procedures or equipment between the member countries of the alliance (Rogowski, Woźniak, 2018). Each NATO state ratifies a standardization agreement and implements it within their own military. The purpose is to provide common operational and administrative procedures and logistics, so one member nation's military may use the stores and support of another member's military. Moreover, standardization agreements form the basis for technical interoperability between a wide variety of communication and information systems essential for NATO and Allied operations.

NATO regulations, from the group of standardization agreements, are implemented in a correct, continuous manner with the aim of ensuring quality in the procurement of defense products. They are supervised by the UK. The NATO process, which seeks mutual implementation of governmental quality assurance, creates the Aliance policy through guidance on inter alia, an integrated systems approach to quality through the life cycle (AQAP 4107:2018 SRD.2, 2018), quality plans (AQAP 2105:2019, 2019), quality assurance in design, development and production (AQAP 2110:2016, 2016), quality assurance for aviation, space and defense suppliers (AQAP 2310:2017, 2017) and quality assurance for final inspection and test (AQAP 2131:2017, 
2017). The above individual standards ensure the preparation of a quality assurance system for providing supplies and services in accordance with NATO guidelines. An organization that takes action to implement two types of documents - AQAP guidelines and AQAP contracts (Jasińska and Pokora, 2005) - prepares for the possible implementation of the standard AS/EN $9100 \mathrm{Rev}$. D, which is a requirement for providing services and supplies for the international defense, space and aviation industry. It should be pointed out that based on AQAP requirements, the supplier should establish, document, apply, evaluate and improve an effective and economical quality management system in accordance with quality requirements contained in the implemented standard (AQAP 2310:2017, 2017).

Another relevant point are guidelines for industry, including defense industry, in the area of quality assurance in design, development and production. It is recommended to apply mechanisms for approaching risk in the analysis of hazards in the designed systems based on implemented security systems in the logistics chain (Gontarczyk, Marcinkowska, 2020).

Practical applications of systems security standards are also developed by the United States Department of Defense in the area of systems engineering. It implies eliminating hazards, where possible, and minimizing risks where those hazards cannot be eliminated (The United States Department of Defense, 2012). The instructions recommended by the US Department of Defense are based on international defense standards. They define the hazards identified in systems, products, equipment, infrastructure and in the processes of design, development, test, production, use and disposal. The defined requirements for acceptable levels in the system and the overall procedure of hazard and risk analysis are based on NATO's international AOP-52 document, which is a guidance on software safety design and assessment, excluding occupational safety and health issues (The United States Department of Defense, 2019). Within this guidance, risk analysis is a key tool in managing hazards in the process from concept to final product in the defense and aviation industry.

According to US guidelines, the risk analysis on the basis of hazard analysis in design, development, test, validation and production should be carried out in accordance with the System Safety Standard - practical guide MIL-STD-882E (The United States Department of Defense, 2012), Occupational Safety and Health in Human Engineering Design - MIL-STD-1472G (The United States Department of Defense, 2019), and Software System Safety Design - AMCOM Regulation 385-17 (United States Army Aviation and Missile Command, 2008) and last of all based on contract-specific quality plans, customer requirements and quality management system standard within the aviation, space and defense industry - AS9100 Rev. D (IAQG, 2015).

Specific criteria contained in the instructions for use require a first pre-contract risk assessment within 90 days prior to the functional audit DI-SAFT-80102C (The United States Department of Defense, 2015). The second phase of the mandatory risk 
analysis should be carried out within 90 days after contract completion. It includes verification and monitoring of the hazard analysis and associated risks along with a description of the requirements for system safety DI-SAFT-81626 (The United States Department of Defense, 2001). The third required deadline for the risk analysis shall be 90 days prior to the final product review for transfer to the full-scale production, assembly, integration and testing process DI-MISC-81397C (AIA, 2014).

At nearly every stage of product design, up to handover to the customer, the risk analysis should be carried out continuously taking into account the knowledge of experts supporting engineers and the overall process. According to the guidelines of the standards, these experts are specialists with experience in design, integration and testing as well as system reliability, logisticians, occupational health and safety professionals, verifiers of suppliers and sub-suppliers, specialists implementing and supervising customer requirements and tradespeople. Another integral aspect is the quality which allows to meet the requirements for documenting quality plans, configuration, product ageing, handling of foreign objects, counterfeit parts and analysis at each stage of product design. These guidelines for conducting hazard and risk analysis emphasize that hazard analysis should be conducted using expert knowledge to support engineering designers. It means applying techniques used in qualitative and quantitative analysis to identify hazards, their causes and effects, and recommended corrective actions. The applied techniques and analyses should identify hazards associated with the system, subsystem, components, personnel, facilities and their interrelationships in logistics support, training, maintenance, transportation and operational environment (AIA, 2014). In practice, the analysis of hazards and associated risks involves three steps. It is essential to have qualified personnel (see: expert group described above), where people are organised in working groups and have sufficient project knowledge.

The risk assessment cycle starts with three basic steps. The first step is the arrangement of expert meeting with the product design engineering group to review the system and client requirements. The aim is to investigate how the system works and how it was designed. The analysis should also include the software, configuration, equipment, materials, components and applied methods. This analysis demonstrates what causes problems and allows to identify the hazards.

The second step is determining what or who causes problems and in what manner. For each hazard, the team should be asked how someone or something causes problems and how it happens. Then the team should be asked about the severity of the harm that may or has occurred and possible reasons. At this point the team should identify the conditions under which the risk occurs, which can be defined as the risk levels (control points).

The third step is the presentation of the course of risk and deciding which risk levels are acceptable and to which mitigating actions should be applied to minimize the risk. In practice, risk assessment is done by identifying low, medium and high 
risk levels. Subsequently, additional possible risk levels should be identified or system changes should be made against the basic requirements. It is recommended to continuously record the findings. The risk assessment should be regularly reviewed, verified and controlled.

To demonstrate the hazard and risk analysis process based on an example, the next part of this article will present the causes of hazards and risks associated with the failure to meet the requirements of the standard in a company planning to enter the international supply chain.

\section{Hazard and risk analysis in a company entering the international supply chain}

Firstly, it is worth pointing out that international norms and standards are voluntary. If the concluded contract or bilateral agreement does not impose their implementation, the company makes a decision on which standard to implement and to what extent it should be implemented based on specific business objectives (Gontarczyk, Marcinkowska, 2020). For instance, having analyzed the current state in the Polish and foreign market, a Polish manufacturing company operating in the power engineering market decided to implement the requirements of AS9100 Rev. D - referred to in the rest of this article as "the standard" - into one production process.

The process is facilitated by the fact that the company implemented, certified and applied ISO 9001:2015 system. Additionally, the company, pursuing an expansion policy for European markets (Germany, Italy, the Czech Republic, Ukraine), has implemented such standards and obtained certificates of conformity for the fusion welding of load-bearing steel structures used in the construction industry in accordance with DIN EN ISO 3834-2, for factory production control in accordance with EN 1090-1:2009, for supporting structures on all construction type with A1:2011, and a certificate confirming the use of technology for electrical refurbishment and blast-resistant construction in the organization in accordance with PN-EN 60079-19:2011. The application of the principles set out in the above standards guarantees safety during the execution of contracts, including operating in explosive environments.

In the course of business, a risk analysis of the implementation of the standard was conducted using a sampling strategy. The purpose of sampling is to collect objective evidence to identify hazards and associated risks of failure to meet the requirements of the standard in the production process covered by the certification. As a part of the identification of potential risks, observations and analysis were conducted in the areas of the company, i.e. organization management, organization objectives, management responsibility. 
The company implemented procedures and processes in accordance with the requirements of ISO 9001:2015. A quality manual for the standard is maintained separately. In the quality manual for the standard, the quality policy was not adjusted. The current version of the policy does not confirm the commitment of top management to meet the requirements of the implemented standard. This results in a hazard that these two quality documents will be inconsistent and will not overlap in the part which is common to these two quality standards and the company management system itself.

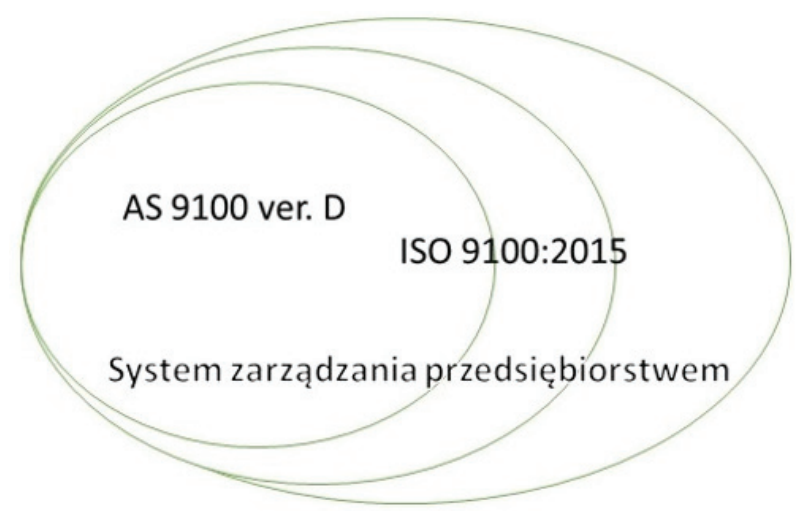

Fig. 2. Relationship between the company quality management system, standard ISO 9001:2015 and standard AS9100 Rev. D.

Source: Author's own elaboration

Considering the company management efficiency, the quality manual contains elements which should be moved to the lower-level documentation. These are checklists of equipment and machines, inspection schedule, lists of spare parts, lists of employees, register of control and measurement tools.

The process maps contained in the quality manual do not include inputs and outputs for the identified processes - their mutual relationship and interrelationships. This entails a risk of failure to comply with clause 4.4.1 of the standard. In this section, it is stated that the organization should establish, implement, maintain and continually improve the quality management system, including the processes needed and their interactions, in accordance with the requirements of the standard.

During the review of the documentation, it was found that the SWOT analysis contains the processes, while it should also be conducted at the management level, taking into account the stakeholders and the impact of the market on the company's activities. Due to the lack of such an analysis in the quality manual, particular attention should be paid to the requirement from clause 6.1.1 of the standard. The company should implement actions to address risks and opportunities. 
In the next step, the indicators defined by the company were verified. This demonstrated that the company maintains the metrics described by the specific processes and records them using process monitoring cards. In the case of one of the processes, the verification of the results showed that the indicators have not been achieved since 2020 . Despite the fact that the target for the indicator of the implementation of the training plan and follow-up requests is $>70 \%$. The value achieved is $0 \%$ for the first 3 months of 2021 and $12.9 \%$ for the half-year. The company did not conduct a verification of the validity of the set objectives. This means that although the risk cause concerning point 4.1.1 of the standard was known, the corrective actions were not introduced.

With reference to clauses 5.1.1 and 7.4 of the standard, there was no evidence of meeting the requirements concerning the communication of the achieved results in the enterprise to the personnel at each level. In terms of the documented information, the company keeps records of the undergoing works within the production guides and accompanying documentation, i.e. general manufacturing techniques. This means that the company meets the requirements of clause 7.5 of the standard.

Another risk is failure to comply with clause 7.5.3 of the standard, which was not met during the performed documentation review. The reviewed documentation revealed manual corrections/corrections with no indication of the date and author of the change. At the review stage, it was not possible to judge whether the person introducing the changes was entitled to authorize them. The entries made by circling covered the original entry and thus it was not possible to assess when the change in the document occurred. This falls under the risk of non-compliance of the facts with cause 8.5.6 of the standard.

After reviewing the production guide, it was found that it did not include the sequence of performed operations, the phases of control and the stages at which control takes place throughout the processing cycle. This is a significant risk of non-compliance with clause 8.1 of the standard. It was suggested that the manufacturing operations concerning the aviation production must include information on the applied tools, instruments and technological aids. At this stage it is necessary to consider the compliance of the issued routes / work guides / work cards to ensure that they explicitly contain all guidelines from clause 8.1 of the standard.

The process guides do not refer to the instrumentation needed to make a compliant product and to the internal transport between two workstations. The company should include risks such as the improper use of the wrong transport truck or tools in the risk analysis at the operational level.

After verifying the actual state against the clause 8.2.3.1 of the standard, it was suggested to improve the review of the customer requirements at the stage of verification of request for quotation. This review should be documented and its results should be accepted before issuing the commitment. A documented review does not mean loose notes with no indication of the author, date and requirements concerning the approval and storage of such data in accordance with 7.5.3 of the standard. 
In terms of clause 8.4.1 of the standard, the organization is in compliance with the requirements within the aviation production activities. This area was supported by a representative sample and was subject to the assessment of adequate authority oversight of the approved external providers.

Another area covered by the representative sample was the quality control in the mechanical engineering department and two workstations where the acticities covered by the new certification are planned. In the area of the management of control and measuring equipment, information about the validity of tests for a furnace was identified. Such information can be found on each device equipped with measurement and control instruments. This is the evidence of the proper supervision of the control and measuring equipment, which demonstrates the conformity to clause 8.1.5.2 of the standard. Clear information about the current status of the equipment was included for the operator. Proof of calibration of a caliper used in the performed production work was also provided. The organization ensured access to information concerning the product each time when necessary, which meets the requirements of clause 8.6 of the standard.

The risk is caused by the lack of identification of non-compliant products, which was revealed during the inspection. The scrap and used parts are stored directly at workstations without their identification and protection against unintended use, which does not meet the requirement of clause 8.7.1 of the standard. A station with raw material collection is not organised in a manner ensuring its proper inspection. Loose elements of technological instrumentation (coils) and scrap rejected from production are stored at the station. The collection zones and stations are not described in terms of production planning. It was found that there are no intermediate storage racks for finished products. This may disturb the management of products in accordance with FIFO and the protection of a compliant product in case of a foreign object damage - section 8.5.4 of the standard, which may form the basis for the risk of noncompliance.

The following corrective actions were recommended as a result of the risk analysis concerning the hazard of noncompliance of the functioning processes in the company with the requirements of the standard. As regards the quality manual, the enterprise should include the required minimum. It was recommended to create separate forms as attachments to the appropriate procedures or processes so that the described data can be supervised and corrected without the need for changes in the quality manual and the participation of the top management. Additionally, it is worth updating the map of processes included in the quality manual by adding inputs to processes (e.g. customer order, specifications, standards) and outputs from processes (e.g. customer). It is suggested to complete the entries in the quality manual with an analysis covering the overall organization. The analysis would include the impact of third parties and political or pandemic factors on the functioning of the organization. In terms of metrics, the validity of the set objectives and metrics should 
be verified. The objectives should be SMART and the metrics should be controlled and achieved. If this is not the case, effort should be made to correct this state (change of indicator during additional management review, change of target value, initiation of corrective actions). The results of the review of goals and metrics achieved by the organization should be communicated to all employees in the company, through information boards, visuals etc. It is not necessary to include all indicators. Top management can select the indicators, e.g. productivity, poor quality costs. If they do not want to publish financial data, it can be omitted. In the existing quality manual, it is necessary to describe the rules which state who has the autohority or position to introduce manual changes and corrections in the technical and quality documentation and how to do it properly. A correction should be made by a single horizontal strikethrough of the incorrect entry, which will enable to read the wrong information. Then the entry with the correct information should be entered next to it or in other possible place. It is necessary to include the date of change and the signature of the authorized person introducing this change. The list of authorizations should include the authorization of employees who can make such changes in the documentation. It was recommended to give a clear description and sequence of operations in the work cards issued to the production department: 1 - sampling material, 2 - cutting to size, 3 - between-stages tests, 4 - storage, etc. The employee starts the next operation after the previous one has been correctly completed and confirmed with a signature or a stamp and after the quality controller confirms the inspection at the predetermined/scheduled stage of production. It was also recommended to complete the formalities for proper identification of both the product and the technical intrumentation that affects the final quality of the product. In this case, the technology should include and designate the type, method and type of transport applied during the movement of materials inside the workshop and technological instrumentation: cutting tools, coils, measuring tools (not necessarily from the inventory number but from the catalog type).

It was proposed to establish a formal document (or preferrably a system solution) that retains review information, remarks and risk analysis for the different organizational units involved in the inquiry and procurement review, The idea of this approach is to make sustainable decisions at this stage and to be able to improve the process, which often cannot be done without historical data. Additionally, the description involved changes the organization should introduce to the documentation and aspects which should be supported by appropriate internal training conducted for the employees of the company (who might be concerned). The records from such training should be kept and archived.

It was suggested to consider the requirements concerning the required periods of documentation archiving in the organization. Personnel data should be retained for up to 50 years. The archiving period for aviation parts period is 10 years, but in case of critical parts it is as many as 40 years. As a part of continuous improvement, 
it was proposed to verify the training needs of the personnel in the area of the adopted quality management system, after the introduction of changes concerning the supervision of records and changes.

In the area of human resources, the company stands a good chance to minimize risks by implementing corrective actions, because the personnel is highly involved in the process of preparation for the certification, which provides a solid foundation for further development.

\section{Final conclusions}

The applicable methodology of analyzing hazards and associated risks, conducting corrective and preventive actions, and continuous monitoring and control are the key elements in the proper identification of the situation of a given company in the domestic and international market. The methodological approach to risk analysis and the long experience of the international market prove that these mechanisms have been known and used for many years. The benefit of hazard and risk analysis is above all the consideration of requirements of the customer, supplier and sub-supplier for a particular supply or service. The unification of provided services and products increases the competitiveness of enterprises, especially during tendering process, where the most often selected suppliers are those who implemented aviation or defense standards. It is through the unification of quality standards of products and services that companies gain opportunities to sign contracts for supplies and services for the defense and aviation sector in Poland and other NATO countries.

Another possible situation is minimizing the risk of misunderstandings between the ordering party and the supplier. From the point of view of the company itself, the effectiveness of processes in the organization is increased by minimizing the costs of current activities of the company, determining the optimal personnel needs, proper management of machinery and transport, optimizing the process of purchasing and price negotiations. Furthermore, the company is protected against loss of financial liquidity. Moreover, the implemented standards and norms along with the implemented analysis of hazards and associated risks are tools that provide evidence of conforming the quality of organization management to the requirements of the defense and aviation market. Additionally, in the case of small companies, the opportunity to compete with larger organizations that also implemented NATO and/or other international or national standards.

Companies that manage risk effectively and efficiently are more likely to achieve their strategic goals and objectives at a lower total cost (Gontarczyk, Marcinkowska, 2020).

Based on the presented methodology for analysis of hazard and identified risk, its monitoring and control, and by presenting the location of risk in the national and 
international civil and defense standards, it should be clearly stated that risk analysis has a key impact on the decision-making processes in companies wishing to meet requirements in the international supply chain. Risk analysis, which is continuously conducted, monitored, verified and controlled, allows to avoid non-compliance with the standards implemented in the enterprise and deviation of the actual state from the established processes and procedures. As stated based on the example of a company implementing a quality management system to provide services for the aviation and defense industries, the key mechanism is communication and teamwork in the organization. Regardless of the management level, all employees participating in the implementation of the company's business objectives should be provided with the knowledge and tools that allow them to perform their duties correctly, on time and under appropriate conditions. In this way, the can contribute to the implementation of the company's strategy.

The process of risk management, monitoring, control and continuous improvement at different levels of management must be communicated and implemented by people who are able to communicate with top management, the operational level and employees at the lowest levels. A fundamental task in any organization is to communicate and explain risk and its mechanisms using concrete, simple examples that everyone can understand. Every employee at every level of management must know and understand the ability to define the hazard and associated risk, its relevance to a given area or process and the ways to find a solution to minimize risk. If such skills are implemented and clear to the risk owner, the very process of monitoring and controlling the level of risk takes place automatically and brings measurable effects for the strategic goals of the company. The foundation of any company is a team which means people, their skills, level of general and technical knowledge, experiences, weaknesses, relationships, impact of the environment in which they live, political system. Depending on the personnel at the management and operational their level of technical expertise and attitude towards the company's business goals, it is possible to identify the capabilities of the remaining personnel to implement changes and innovations. In the analyzed case, despite significant non-compliance with AS9100 Rev. D standard, it is the commitment of the staff that provides a solid foundation for the implementation of the standard. The most common examples of incorrect expert forecasts in the enterprises are lack of imagination, excessive caution not to compromise oneself, focus on certain and well-known solutions, lack of ability to predict converging events and competing systems, miscalculation and other phenomena (Bogdanienko, 2020).

In the conducted analysis of the research problem on the specified example of an enterprise implementing an international standard, the stated research hypotheses were confirmed. The case study proved that hazard and risk analysis in the organization is carried out ad hoc despite the fact that the enterprise is certified to ISO 9001:2015 standard according to which the risk analysis is one of the basic 
processes that should function in the organization. The risk management process is not documented at different management levels and is performed for evidence purposes for internal and external audits. However, there is an added value for the organization in the process of continuous monitoring of risk mitigating actions, provided it is performed by the professional and reliable personnel. If the employees are convinced of the validity and purpose of the risk analysis and management, they will carry out the process continuously and with tangible results for the company.

\section{BIBLIOGRAPHY}

[1] Bogdanienko, J.,(2020). Risk and Crisis in the organization development process. Warszawa: CeDeWu.pl.

[2] Braman, G.D., (2018). Introduction to System Safety. In Sikorsky Aircraft, (ed.) (2018) Annual Reliability and Maintainability Symposium. Huntsville, CA: 1-20.

[3] Czerwiński, K., Grocholski, H., (2003). Internal audit basics. Szczecin.

[4] Ficoń, K., (2021). Safety chain. Hazards, risk and crises. Warszawa: Bel Studio Sp. z o.o.

[5] Gontarczyk, M., Marcinkowska, A., (2020). Risk increase as a determinant of the purpose of introducing innovations in Logistics. Systemy Logistyczne Wojsk, 52 (1), Warszawa: Wojskowa Akademia Techniczna, 29-41.

[6] Jasińska, J., Pokora, W., (2005). Risk and configuration management in the processes of implementation of armaments and military equipment in the NATO requirements. Zielonka: Wojskowy Instytut Techniki Uzbrojenia.

[7] Kulińska, E., Dendera-Gruszka, M., (2019). Supply chain risk management. Warszawa: Diffin.

[8] Makowski, P., (2020). Risk as a criterion for selecting variants of tactical actions and response in crisis situations. Warszawa: Akademia Sztuki Wojennej.

[9] Moraczewska, A., (2021). Risk management at the external borders of the European Union. Lublin: Uniwersytet Marii Curie-Skłodowskiej.

[10] Rogowski, B., Woźniak J., (2018). Polish defense standards in the European basis for recommended defense normalization (EDSTAR) documents. Systemy Logistyczne Wojsk, 49 (1), Warszawa: Wojskowa Akademia Techniczna, 174-184.

[11] Staniewska, E., (2021). Selected aspects of supply chain security management. Systemy Logistyczne Wojsk, 54 (1), Warszawa: Wojskowa Akademia Techniczna 135-148.

[12] Woźniak, J., Zaskórski, P., (2018). Design a process of the organization. The perspective of analytical and decision-making systems. Warszawa: Wojskowa Akademia Techniczna.

[13] AS/NZS 4360:2004, The Australian and New Zeland Standard on Risk Management. (2014). Sidney, Modern Economy.

[14] ISO 31000:2009, Risk Management - Principles and guidelines. (2009). New Zeland, Standard Australia.

[15] ISO 31000:2018, Risk Management - Guidelines. (2018). New Zeland, Standard Australia.

[16] Ministry of Defense of the Republic of Poland, Decision no. 126 Ministry of Defense from 16th of August, 2019 on quality assurance of military equipment and services related to military equipment (Dz. Urz. MON z dnia 23 sierpnia 2019 roku, poz. 159).

[17] NATO. AQAP 4107:2018 SRD.2 AQAP selection guidance. (2018), Centrum Certyfikacji Jakości Wojskowej Akademii Technicznej w Warszawie. 
[18] NATO. AQAP 2105:2019 NATO Requirements for Quality Plans. (2019), Centrum Certyfikacji Jakości Wojskowej Akademii Technicznej w Warszawie.

[19] NATO. AQAP 2110:2016 NATO Quality Assurance Requirements for Design, Development and Production. (2016). Centrum Certyfikacji Jakości Wojskowej Akademii Technicznej w Warszawie.

[20] NATO. AQAP 2310:2017 NATO Quality Management System Requirements for Aviation Space and Defence Suppliers. (2017). Centrum Certyfikacji Jakości Wojskowej Akademii Technicznej w Warszawie.

[21] NATO. AQAP 2131:2017 NATO Quality Assurance Requirements for Final Inspection and tests. (2017). Centrum Certyfikacji Jakości Wojskowej Akademii Technicznej w Warszawie.

[22] NATO. STANAG 4107, (2019). Mutual Acceptance of Government Quality Assurance and Usage of the Allied Quality Assurance Publications (AQAP). (Wydanie 11), Centrum Certyfikacji Jakości Wojskowej Akademii Technicznej w Warszawie.

[23] US Department of Defense, (2019). MIL-STD 1472G. Design criteria standard. Human engineering. Public Domain Mark.

[24] US Department of Defense, (2012). MIL-STD 882E. The system safety standard practice. Public Domain Mark.

[25] US Army Aviation and Missile Command. AMCOM 385-17. Software system safety policy. Public Domain Mark.

[26] US Department of Defense, (2015). DI-SAFT-80102C. Safety Assessment Report. Public Domain Mark.

[27] US Department of Defense, (2001). DI-SAFT 81626. System Safety Program Plan. Public Domain Mark.

[28] Aerospace Industries Association (AIA), (2014). DI-MISC-81397C. Hazards materials management program. Public Domain Mark.

[29] The International Aerospace Quality Group (IAQG), (2015). AS9100 ver. D Quality Management Systems - Requirements for Aviation, Space and Defense Organization. 
